\title{
Study on the Scientific Research in Private Colleges
}

\author{
Guangdao Li \\ Eastern International Art College \\ Zhengzhou University of Light Industry \\ Zhengzhou, China 451450
}

\begin{abstract}
Talent cultivation, scientific research, society service and culture inheritance and innovation are the basic functions of colleges. Undoubtedly, private colleges also have the function of scientific research. With the continuous development of private higher education, scientific research becomes a constraint for the connotative development and sustainable development of private colleges. However, since most private colleges originate from occupational education with short school running history and late scientific research, the following problems exist in their scientific research: insufficient notion cognition, unreasonable talent structure, insufficient fund investment and unsound system, etc.
\end{abstract}

Keywords—private colleges; scientific research; funds; system

\section{INTRODUCTION}

Scientific research lag is always a ubiquitous problem among private colleges. Since most of private colleges originate from occupational education, they are featured on higher vocational education and applied talents cultivation; their discipline construction and major setup are mainly market-oriented, so some private colleges start to seek quick success and instant benefits with incorrect scientific research orientation. In addition, most of private colleges belong to teaching-oriented colleges with short school running history and insufficient management and fund investment in scientific research, which reflecting the indifference of private colleges' management to scientific research; as a result, the scientific research system is not sound and the scientific research atmosphere is not good. The following four problems are the main problems in the scientific research of private colleges.

\section{CONCEPTUAL PROBLEM}

Conceptual problem mainly means the problem in the understanding of founder, the management and the teachers of private colleges on scientific research. Private colleges make development in the market environment; they are mainly invested by enterprises, public institutions, private person, etc.; they charge the students according to teaching cost, with relatively strong awareness of market and management benefit. Therefore, in view of school running guiding ideology, many investors and founders of private colleges emphasize particularly on teaching and neglect scientific research. They have not recognized the significance and impact of scientific Study on the development of colleges and the improvement of school running level. Because of the wrong school running guiding ideology, some private colleges' understanding on "focusing on teaching" is one-sided; they think scientific research is the responsibility of public colleges and research institutes and it is not important to do scientific research, while what they should do is to ensure high-quality teaching.

On the other hand, teachers of private colleges have wrong understanding on scientific research. Most of the teachers of private colleges are young with relatively low education level and title level. They emphasize particularly on teaching and neglect scientific research; their understanding on the relationship between teaching and scientific research is not correct. In addition, the insufficient scientific research condition, bad scientific research atmosphere and obstacles in project application and assessment in private colleges lead to the weakness of scientific research awareness of teachers of private colleges; namely, they are lack of the awareness of doing scientific research initiatively.

\section{TALENT PROBLEM}

Talent problem means the problem of teachers of private colleges. On the one hand, the structure of teachers of private colleges is not reasonable: the proportion of senior title teacher and highly educated teacher is low; the quantity of young or old teacher is large while the quantity of middleaged teacher is small, so the overall foundation of teachers of private colleges is relatively weak. The incompetence of teachers of private colleges and the lack of academic leader are the adverse factors for the implementation of scientific research in private colleges. On the other hand, the implementation of scientific research needs stable teacher team and stable and reasonable scientific research team; however, the instability of teacher team of private colleges will go against the implementation of scientific research in private colleges. Most of the teachers initially appointed by private colleges are graduates; after many years of working, most of these teachers obtain master degree or doctorate and deputy senior title or senior title through further study; these teachers are the core talents in private colleges and they are competent for scientific research in respect of their capacity, education background and title; however, the reality is that the quantity of these core talents is small and most of them are transferred to administrative posts, so their time for scientific research is insufficient. 


\section{FUND PROBLEM}

The implementation of scientific research needs the support of fund and fund problem plays an important role in the implementation of scientific research in colleges. Usually, a scientific research project can be realized after purchasing necessary books, equipments, apparatus and relevant office supplies and providing allowance for scientific research personnel, which shall be guaranteed by certain fund.

The sources of scientific research funds mainly include obtaining fund through applying for governmental project approval, obtaining fund through establishing relationship with enterprises and public institutions and guaranteeing scientific research fund through their own economic strength. Since the faculty is relatively weak without academic leader and stable scientific research team, private colleges have no advantage over other public colleges in applying for governmental scientific research projects. Among the national education science " 10 th five year plan" projects published from 2001 to 2005, only 5 projects were undertaken by private colleges; projects undertaken by private colleges and of private schools of other level only account for $0.4 \%$ of the total projects. The scientific research strength of private colleges is weak, so it is difficult for them to obtain scientific research fund through establishing relationship with enterprises. The prospective of guaranteeing scientific research fund through their economic strength is also not good. The fund source of private colleges is simple, which basically tuition fee from students. The associate researcher of CNIER higher education research center Fangyong indicated in the paper Analysis on the Fund Source of Private Colleges in Our Country: in 39 private colleges, there are 14 whose tuition fee income accounting for $100 \%$ of the total income of the school, 9 accounting for $90 \%, 8$ accounting for $80 \%, 4$ accounting for $70 \%, 1$ accounting for $60 \%, 1$ accounting for $50 \%$ and 1 accounting for $40 \%$. From this we can see that there are 31 colleges whose tuition fee income accounting for over $80 \%$ of the total income of the school, about $82 \%$ of the number of colleges investigated. In addition, a considerable number of private colleges are saddled with bank loans; the above mentioned factors all lead to the fact that private colleges cannot invest much in scientific research.

\section{SYSTEM PROBLEM}

The system problem encountered in the scientific research of private colleges mainly comes from the government and private colleges.

Firstly, the current scientific research system of private colleges in our country is government oriented scientific research system; the scientific research system of private and public colleges is the same. The competition between scientific researchers of private and public colleges is not fair in the face of education authorities and scientific research project management and approval units. Because of the prejudice of the society (including education authorities and scientific research project management and approval units) against private colleges, the latter will encounter certain obstacles in the implementation of government oriented scientific research projects. The adverse factors in the scientific research by teachers of private colleges include: difficult to apply for project, be discriminated against scientific research project approval, few scientific research opportunity, limited application condition, etc. In the current scientific research system of our country, scientific research is led by the country and the government and scientific research projects shall be appraised and selected by various levels of education authorities. Each scientific research project shall go through the following procedures: topic selection, application, project approval, review, etc. From topic selection, application, project approval and research to final result publication, scientific research project shall go through many procedures, which is a challenge for private colleges with short school running history.

Secondly, there is problem in the scientific research system of private colleges. The problem in the scientific research system of private colleges is reflected in the following two aspects: Firstly, there is no professional and efficient scientific research administration, so the scientific research is disordered, which influences researchers' scientific research efficiency. Secondly, there is no sound scientific research system and scientific research incentive mechanism, which influences the teachers' enthusiasm in implementing scientific research. The scientific research environment of private colleges is not perfect; the scientific research atmosphere is not good; the academic exchange opportunity is insufficient; these also influence the implementation of scientific research. In addition, teachers of private colleges always face heavy workload, which also influence their implementation of scientific research. Private colleges have not created good scientific research environment and have not provided perfect institutional guarantee for teachers' implementation of scientific research.

As for scientific research administration, the author selected the top 20 private colleges(including Beijing City University, Hunan International Economics University, Yang-En University, Nanchang Institute of Technology, Huanghe Science and Technology College, etc.) in the ranking in 2012 China College Evaluation and Research Report published by CUAA on Jan. 9, 2012 for research. The research shows that there are 15 colleges with independent scientific research office or department and the rest are without 5 colleges with independent scientific research office or department; there are 11 colleges with independent scientific research website, in which the scientific research website of 9 colleges are relatively sound; however, the other 9 colleges have no independent scientific research website.

As for scientific research reward mechanism, according to the provisions of Scientific Research Project Application and Reward Method of Huanghe Science and Technology College (Trial) published by the first private general fouryear college in China, Huanghe Science And Technology College on Jul. 2, 2010, the highest reward is 2500 Yuan and the lowest reward is 900 Yuan for province-level and department-level scientific research projects according to the project type. However, according to the Scientific Research Reward Method of Zhengzhou University of light Industry (Trial) issued by the public university, Zhengzhou University 
of light Industry on Jan. 1, 2009, “a 10 thousand Yuan reward will be given to each province-level and departmentlevel project, talent project and scientific and technical innovation team". As for the same level of project, the latter is 4 times the reward for the former, or even 10 times the reward for the former for some projects.

As for scientific research achievements publication platform, according to the Study on the top 20 private colleges, there are 5 colleges without journal, and the rest 15 colleges all have journal. Through the inquiry by entering "journal" in the "news agency inquire" column in the website of The Press and Publication Administration of the People's Republic of China, so far, there are 1945 journals published and issued in the whole country; in the 15 colleges with journal, only the journal of Huanghe Science and Technology College, Beijing City University, and Zhejiang Shuren University (namely the Journal of Huanghe Science and Technology College, the Journal of Beijing City University and the Journal of Zhejiang Shuren University) are published and issued by The Press and Publication Administration of the People's Republic of China, accounting for $0.15 \%$ of the total number of journals published and issued in the whole country. However, each public college has their own journal in average. This is inconsistent with the proportion of private colleges in ordinary universities (namely 1/3) and the swift growth of the number and scale of private colleges.

\section{CONCLUSION}

The above mentioned four problems are interrelated with each other. The founder of private colleges pay little attention on scientific research; the scientific research ability of teachers of private colleges is poor because of their weak scientific research awareness; in the current scientific research system oriented by government, private colleges are disadvantaged and they can not obtain high-level scientific research projects; meanwhile, they are lack of the support of scientific research fund, so it is very difficult for them to do scientific research. The lack of scientific research fund leads to the fact that private colleges fail to attract scientific research talents; conversely, the lack of scientific research talents and scientific research fund prevents the founders of private colleges to promote scientific research, which means those researchers aspired to scientific research have no institutional guarantee and encouragement and that intensify the flight of scientific research talent and the instability of scientific research team; this is a vicious circle that is harmful for the implementation of scientific research and the sustainable development of private colleges.

\section{REFERENCES}

[1] Qian Weichang. The Barrier between Teaching and Scientific Research shall be Removed by Colleges [J]. Qunyan, 2003, (10).

[2] Fang Yong. Analysis on the Fund Source of Private Colleges in Our Country [J]. University (research and assessment), 2007, (03).

[3] Zheng Lijun. Study on the Status of Scientific Research of Private Colleges [J]. Journal of Beijing City University, 2006, (04).
[4] Chen Jie. Survey on the Status of Scientific Research of Private Colleges in Our Country [J]. China Adult Education, 2008, (02).

[5] Cheng Changchun. Win the future- Study on the Core Competitiveness of Colleges [M]. Beijing: People's Publishing House, 2006 